УДК 378.147:811.111:004]:355.92:005.336.2(043)

\title{
КРИТЕРІЇ ВІДБОРУ ВІДЕОМАТЕРІАЛУ ДЛЯ ФОРМУВАННЯ ПРОФЕСІЙНО ОРІЄНТОВАНОЇ КОМПЕТЕНТНОСТІ В АНГЛОМОВНОМУ ДІАЛОГІЧНОМУ МОВЛЕННІ КУРСАНТІВ З ІНФОРМАЦІЙНИХ СИСТЕМ ТА ТЕХНОЛОГІЙ
}

\author{
Юхименко В. О. \\ violetta-yukhymenko@ukr.net \\ https://orcid.org/0000-0002-7039-4741 \\ Військовий інститут телекомунікацій та інформатизаиії імені Героїв Крут \\ Дата надходження 19.12.2019. Рекомендовано до друку 24.01.2020.
}

\begin{abstract}
Анотація. У статті виокремлено й описано критерії відбору відеоматеріалу для формування професійно орієнтованої компетентності в діалогічному мовленні курсантів з інформаційних систем та технологій. Обгрунтовано необхідність використання відеоматеріалів як джерела поповнення словникового запасу курсантів професійно орієнтованими лексичними одиницями й граматичними структурами. Подано результати анкетного опитування офіцерів (спеціальність інформаційні системи та технології) Київського й Житомирського військових інститутів. Виділено тематичний розподіл групування лексики за професійним спрямуванням, а також структурні типи англомовних військових скорочень в усному мовленні. Зазначено, що для семантизації англомовної професійно орієнтованої лексики слід використовувати безперекладний спосіб.

Ключові слова: критерії відбору англомовного відеоматеріалу, військова термінологія, невербальна комунікація військових.
\end{abstract}

Юхименко В. О. Киевский военный институт телекоммуникаций и информатизации имени Героев Крут

Критерии отбора видеоматериала для формирования профессионально ориентированной компетентности в англоязычной диалогической речи курсантов по информационным системам и технологиям

Аннотация. В статье выделены и описаны критерии отбора видеоматериала для формирования профессионально ориентированной компетентности в диалогической речи курсантов по информационным системам и технологиям. Обоснована необходимость использования видеоматериалов как источника пополнения словарного запаса курсантов профессионально ориентированными лексическими единицами и грамматическими структурами. Представлены результаты анкетного опроса офицеров (специальность информационные системы и технологии) Киевского и Житомирского военных институтов. Представлено тематическое распределение лексики профессиональной направленности, а также структурные типы англоязычных военных сокращений в устной речи. Отмечено, что для семантизации англоязычной профессионально ориентированной лексики следует использовать беспереводной способ.

Ключевые слова: критерии отбора англоязычного видеоматериала, военная терминология, невербальная коммуникация военных.

Yukhymenko V. Kyiv Military Institute of Telecommunications and Informatization named after Heroiv Krut

Criteria for the selection of video materials for formation of the professional competence in English oral interaction of cadets of information systems and technologies

Abstract. Introduction. Understanding of the professional English oral interaction enables military professionals to share the necessary information with their English-speaking colleagues, which determines the selection of video materials from the Internet as an example for studying English oral interaction. The selected video material helps cadets master the vocabulary minimum, clichés, non-verbal means, which are used in authentic English 
military videos. Purpose. To distinguish the criteria for the selection of video materials for development of the professional competence in English oral interaction of information systems and technologies cadets. Methods. Reviewing the studies on applying video materials as a source of studying languages, conducted abroad and in Ukraine. The questionnaire surveys held among information systems and technologies officers of Kyiv and Zhytomyr Military Institutes. Results. The research showed that the military terminology is the most used in the professional activity of military specialists (42\%), technical (40\%), nomenclature (27\%), abbreviations $(10 \%)$.The thematic of professional oriented vocabulary grouping according to technical features of communication and information systems; command and control; combat operations and data protection; radio communications and networks; newest technologies in the field of radio and security, as well as structural types English-speaking military abbreviations in verbal speech (truncated words, abbreviations, acronyms). It is noticed that for acquiring English professionally oriented vocabulary it should be used non-translatable method of words semantization. Conclusion. The author reveals the main criteria for the selection of authentic video materials, summarized the list of typical tasks and situations for implementation professional English oral interaction of cadets.

Key words: selection criteria of authentic English video materials, military terminology, non-verbal communication of the military.

Постановка проблеми. Коректне розуміння усного професійно орієнтованого англомовного мовлення дає можливість військовим фахівцям обмінюватися необхідною інформацією 3 англомовними колегами, що викликає необхідність у відборі автентичного відеоматеріалу 3 мережі Інтернет як опори для навчання англомовного діалогічного мовлення. Відібраний відеоматеріал допомагає курсантам оволодіти лексико-граматичним мінімумом, кліше, невербальними засобами, якими наповнені англомовні військові автентичні відеоматеріали інформаційного змісту.

Аналіз останніх досліджень і публікацій. Науковці вже досліджували принципи й критерії відбору відеоматеріалу. Так К. Едельхофф (Edelhoff, 1985) при відборі відеоматеріалу орієнтує увагу на тих, хто навчається, на їхні потреби, знання, досвід, а також рівень навченості. Л. П. Полушина (1995) виділяє такі критерії: цікавість і доступність розуміння відеоматеріалу, а також рівень навчальних можливостей тих, кого навчають. I. А. Ісенко (Исенко, 2009) зауважує на значущості відповідності рівня комунікативної компетентності, інтересів і потреб тих, кого навчають, а також наявності в англомовному автентичному відеоматеріалі навчального, виховного, розвивального потенціалу, який буде реалізовано в процесі післяпереглядової роботи (виконання вправ). О. І. Гузь (2004) наголошує, що одним з найважливіших критеріїв відбору $\epsilon$ автентичність відеоматеріалів.

Мета статті - виокремити критерії відбору відеоматеріалу для формування професійно орієнтованої англомовної компетентності в діалогічному мовленні курсантів з інформаційних систем та технологій.

Основні результати дослідження. Спираючись на вищезазначені дослідження, а також на дослідження Л.М. Конопляник й О. О. Коваленко (2016) і В. С. Пащук (2002), виокремимо критерії відбору відеоматеріалу для формування професійно орієнтованої компетентності в англійському діалогічному мовленні курсантів з інформаційних систем та технологій.

Критерій автентичності. Автентичні відеоматеріали, які містять професійно орієнтовані англомовні діалоги, сприяють збільшенню зацікавленості й творчій взаємодії курсантів, розширенню їхнього словникового запасу (засвоєння й закріплення нових лексичних одиниць); вивченню граматичних структур (опрацювання вивченого матеріалу або презентація нового); формуванню аудитивних умінь (розуміння на слух мовлення учасників діалогу, які є носіями англійської мови) й інтонаційних і вимовних навичок (імітація інтонації та вимова звуків); створенню комунікативної ситуації, що сприяє розширенню знань курсантів з фахових тем (Конопляник, Коваленко, 2016).

Критерій ситуативності. Професійна діяльність сучасного військового фахівця з інформаційних систем та технологій відбувається в умовах різних комунікативних ситуацій: 
1) спілкування щодо систем захисту інформації та кібербезпеки в інформаційнотелекомунікаційних мережах (військові засоби радіозв'язку, розвиток системи зв'язку Збройних Сил України відповідно до стандартів НАТО); 2) спілкування під час (пере)підготовки військових фахівців, курсів підвищення кваліфікації з практичної експлуатації та бойового застосування сучасних цифрових засобів зв'язку; 3) змагання з програмування 3-поміж країнпартнерів НАТО; 4) міжособистісні взаємодії в іноземних військових колективах: спілкування між начальником і підлеглим, між керівниками підрозділів, з колегами одного посадового рівня; 5) ситуації бойового значення - комунікація між учасниками збройного конфлікту в умовах агресивного середовища; 6) спілкування з іншомовним місцевим населенням в екстремальних або мирних ситуаціях.

Автентичні військові відеоматеріали сприяють створенню специфічного мовного середовища у військовому закладі вищої освіти, що надає курсантам можливість опинитись в справжній професійно орієнтованій комунікативній ситуації за умов відсутності реального спілкування з іноземними колегами. Ситуація є вагомим методичним фактором у навчанні англійського діалогічного мовлення (Азимов \& Щукин, 2009; Скалкин, 1958; Пассов, 1989).

Критерій новизни. Новизна зацікавлює курсантів предметною інформацією, що викликає у них мотивацію до навчання, а також бажання обміну думками з колегами щодо почутого й побаченого. Відеоматеріали насичено інформацією про склад іноземної армії, про практичне використання системи зв' язку країн-партнерів НАТО, про особливості комунікації з іноземними колегами й цивільними за різних умов навколишнього середовища. Відеоматеріали інформують про військові події в сучасному світі. Новизна відображається в новому мовному матеріалі: кліше, лексичних одиницях, граматичних структурах.

Критерій соціокультурної цінності. Відеоматеріали ознайомлюють майбутніх військових фахівців із характерною англійською мовою, вербальною та невербальною поведінкою іноземних колег, професійною діяльністю військових фахівців інших країн.

Критерій доступності. Зміст відеотреку відповідає рівню мовної підготовки курсантів (CMP2) та вимогам освітньо-професійної програми з іноземної мови (військово-спеціальна мовна підготовка) для курсантів третього року навчання.

Критерій обсягу. Під час відбору відеоматеріалу ми спирались на рекомендації Бюро міжнародної мовної координації НАTO (BILC) стосовно рівня володіння англомовною компетентністю військовими. Час тривалості аудіо-/відеофрагмента відповідно мовним рівням: CMP1 - 45 секунд; СМР2 - 60 секунд; СMP3 - 90 секунд. Оскільки ми орієнтуємось на рівень СМР 2, відповідно обсяг відібраних нами відеофрагментів складає до 60 секунд. Наповнення аудіо-/відеофрагментів збалансовано різновидами англійського діалекту представників різних країн учасників НATO (BILC, 2019).

Критерій темпу. Темп мовлення у відеоматеріалі має відповідати вимогам рівня володіння англійською мовою курсантами СМР2 (B2). Спираючись на досвід Навчально-наукового центру іноземних мов Національного університету оборони України імені Івана Черняховського, на базі якого відбувається мовне тестування (рівень СМР) військових ЗСУ, ми також використовували посібники з мовної підготовки Кембриджського університету для визначення критеріїв швидкості мовлення: Radio monologues - 160 words per minute, 4,17 syllables per second; Conversation 210 words per minute, 4,33 syllables per second; Interviews - 190 words per minute, 4,17 syllables per second; Lectures to non-native speakers - 190 words per minute, 3,17 syllables per second (Arthur Hughes, 2002).

Критерій тематичної відповідності обраній спеціальності. Відбір відеоматеріалів здійснюється відповідно до напряму підготовки курсантів та їхньої освітньо-кваліфікаційної характеристики бакалавра за спеціальністю “Інформаційні системи та технології” (Міністерство Оборони України, 2017). 
Юхименко В. О. Критерії відбору відеоматеріалу для формування професійно орієнтованої компетентності в англомовному діалогічному мовленні курсантів 3 інформаційних систем та технологій

Також при відборі автентичних англомовних відеоматеріалів ми проаналізували професійний стандарт майбутнього офіцера за спеціальністю інформаційні системи та технології, та узагальнили перелік типових задач (функцій) і відповідних їм цілей англомовного діалогічного спілкування, необхідних для реалізації англомовного діалогічного мовлення за професійним спрямуванням. Адміністративно-управлінська: 1) Ефективно формувати комунікаційну стратегію та обговорення з підлеглими інформації, планів, рішень та власного досвіду в галузі військово-професійної діяльності. Загальновійськова та тактична: 1) Формувати злагоджений бойовий підрозділ, здатність ефективно формувати комунікаційну стратегію. Психологічнопедагогічна: 1) Обговорення 3 підлеглими інформації, планів, рішень та власного досвіду в галузі військово-професійної діяльності; 2). Співробітництва та взаємодії з широким колом осіб для провадження професійної діяльності. Службова (бойова) функція військового спеціаліста 3 комп'ютерної інженерії: 1) Обговорення з фахівцями і нефахівців інформації, ідей, проблем, рішень та власного досвіду в галузі мережевих технологій, обробки та передачі інформації, телекомунікаційних систем та мереж, проєктування та розробки систем та засобів відображення інформації; 2) Взаємодії між підрозділами 3 метою передачі інформації в інформаційно-телекомунікаційних мережах Збройних сил України. Такі цілі англомовного діалогічного мовлення стали орієнтиром при доборі відеоматеріалу для навчання курсантів англомовного діалогічного мовлення.

Відеоматеріали $є$ джерелом поповнення словникового запасу курсантів професійно орієнтованими лексичними одиницями, адже перелік військово-технічної термінології має властивість постійно розширюватись, що зумовлено появою нових військових спеціальностей, техніки, зброї, методів ведення бойових дій (Васильченко, Дормидонтов, Нелюбин, 1981). Саме тому постає питання визначення критеріїв відбору професійно орієнтованих лексичних одиниць.

За основу було взято мовленнєві компетентності відповідно до рівня володіння англійською мовою (рівень В2 або СМР2), що описані в Загальноєвропейських Рекомендаціях з мовної освіти (Council of Europe, 2018, Стандарт НАТО рівень володіння мовою (Stanag 6001, 2019), Посібник з термінології НАТО (NATO Standardization Office, 2019). Відбір навчального матеріалу здійснювався з опорою на анкетування офіцерів за спеціальністю інформаційні системи та технології Київського військового інституту телекомунікацій та інформатизації імені Героїв Крут та Житомирського військового інституту імені С. П. Корольова. Анкета для опитування респондентів була розроблена нами згідно з рекомендаціями науковців (Сисоєва, Кристопчук, 2013). Анкетування відбувалось анонімно та індивідуально в письмовій формі. Результати опитування показали, що в професійній діяльності військових фахівців найуживанішою $\epsilon$ військова термінологія (42\%), технічна (40\%), номенклатурна (27\%), абревіатури (10\%).

Військова термінологія - лексична одиниця, що виконує функції номінації конкретного представника військової справи під час офіційної військової комунікації (Матюшин, 1996). Класифікація військових термінів залежить від майбутньої спеціальності, якою оволодіває курсант. Погоджуючись із думкою Н. Д. Фоміної, М. А. Бакіної (Фоміна \& Бакіна, 1985), ми вважаємо військову лексику особливим прошарком ЛО (лексичних одиниць), яка відображає особливу галузь професійної діяльності людини - організацію Збройних Сил, військове мистецтво, зброю тощо. Військова лексика поділяється на військові терміни (термінологію) та військово-побутову лексику. Військові терміни - слова або словосполучення, що відповідають поняттям військової професії. Військово-побутова лексика $є$ перехідним явищем між військовими термінами та загальновживаним словником (Фоміна, Бакіна, 1985). Результати анкетування збігаються 3 думкою Л. Л. Нелюбіна (Нелюбин, 1981), військові та військовотехнічні терміни займають значний обсяг військової лексики, оскільки мають найбільше змістове навантаження. 
Проаналізувавши відібраний нами навчальний англомовний відеоматеріал для курсантів, ми дійшли висновку, що англомовні діалоги за професійним спрямуванням характеризуються: 1) Загальновійськовими термінами (armed forces, information operations); 2) Військово-технічною термінологією (operating system, software-defined); 3) Номенклатурною лексикою, абревіатурами, військовими скороченнями ( $\boldsymbol{A B C S}$ - army battlecommand system; C4I - Command, Control, Communication, Computers and Intelligence).

Беручи до уваги важливість тематичних групувань військової термінології, ми провели аналіз Натовського глосарію термінів та визначень, розробленого для фахівців за спеціальністю інформаційні системи та технології (NATO, 1994). Було виявлено, що військова термінологія за цією спеціальністю поділяється на три групи термінів: 1) Communication and information systems; 2) NATO information technology terms; 3) Communications. Відповідно до кожного терміна або номенклатурної лексики подається скорочення, абревіатура.

Отже, англомовним відеоматеріалам за спеціальністю інформаційні системи та технології характерний такий тематичний розподіл групування лексики: технічні особливості системи зв'язку та інформаційних систем; командування та управління; бойові операції та захист даних; радіозв'язок та мережі; новітні технології в сфері радіозв'язку та безпеки.

Спираючи на відібраний відеоматеріал, ми зробили висновок, що військова технічна термінологія насичена скороченнями та абревіатурами з метою передачі максимальної кількості інформації під час комунікації між військовими за короткий час. Як зазначають О. С. Мілова, А. А. Дроговоз (Мілова \& Дроговоз, 2018), у військовій літературі скорочення діляться на одно-, дво-, три- чотири-, п'ятикомпонентні і навіть більше. Спираючись на дослідження В. В. Борисова (Борисов, 2004), наведемо уточнення утворення скорочень у військово орієнтованому англомовному усному мовленні. Скорочення діляться на графічні та лексичні. Лексичні скорочення реалізуються в усному мовленні у вигляді абревіатур, акронімів та усічених слів (табл. 1).

Таблиия 1

Структурні типи англомовних військових скорочень в усному мовленні

\begin{tabular}{|c|c|c|}
\hline \multicolumn{3}{|c|}{ Лексичні скорочення (усне мовлення) } \\
\hline \multicolumn{2}{|c|}{ Абревіатури } & \multirow{3}{*}{\begin{tabular}{l}
\multicolumn{1}{c}{ Усічені слова } \\
Утворення за допомогою: \\
скорочення запозичених \\
суфіксів; елізія кінцевої \\
частини слова. \\
Вимовляються: єдиним \\
словом
\end{tabular}} \\
\hline Абревіатури & Акроніми & \\
\hline $\begin{array}{l}\text { Утворення за допомогою: } \\
\text { перших літер; інших частин } \\
\text { слів (які є у складі назви } \\
\text { або поняття). } \\
\text { Вимовляються: відповідно } \\
\text { до алфавітного порядку; } \\
\text { за назвою букв }\end{array}$ & $\begin{array}{l}\text { Утворення за допомогою: } \\
\text { початкових літер; звуків } \\
\text { слів. } \\
\text { Вимовляються: єдиним } \\
\text { словом }\end{array}$ & \\
\hline $\begin{array}{l}\text { CCIS - Command and } \\
\text { control information system } \\
\text { CIS - Communication and } \\
\text { information systems } \\
\text { IM - Information management } \\
\text { IS - Information system } \\
\text { MIS - Management } \\
\text { information system } \\
\text { NICS - NATO integrated } \\
\text { communication system } \\
\end{array}$ & $\begin{array}{l}\text { COMPUSEC - Computer } \\
\text { security } \\
\text { INFOSEC - Electronic } \\
\text { information security } \\
\text { INFOSUM -Information } \\
\text { summary } \\
\text { HALO - high altitude, low } \\
\text { opening } \\
\text { SGT - sergeant } \\
\text { COMD (COM) - command }\end{array}$ & $\begin{array}{l}\text { Capt - captain } \\
\text { Civ-civilian } \\
\text { Coy - company } \\
\text { Med - medical } \\
\text { Intel (Int) - intelligence } \\
\text { Log - logistics } \\
\text { Mil - military }\end{array}$ \\
\hline
\end{tabular}

Примітка: приклади в таблиці наведено автором дослідження. 
Проаналізувавши лінгвістичні особливості англомовного відеоматеріалу, ми з'ясували граматичні особливості англомовного діалогічного мовлення за професійним спрямуванням. Найуживанішими граматичними структурами є такі: форми часових дієслів в Present Simple Active and Passive, Present Continuous Active and Passive, Present Perfect Active, Past Simple Active and Passive, Future Simple Active; модальні дієслова; інфінітив та герундій. Слід зауважити, що військові англомовні діалоги переважно характеризуються чіткими та логічними формулюваннями, які впливають на граматичне оформлення тексту в цілому.

Погоджуючись 3 думкою I. В. Ковалинської (Ковалинська, 2014) та беручи до уваги отримані результати після проведеного нами лінгвістичного аналізу англомовних відеоматеріалів за професійним спрямуванням, бачимо, що комунікація між військовими неможлива без невербальних засобів спілкування. Невербальна комунікація військових - обмін будь-якими знаками між військовослужбовцями, який впливає на їхню поведінку (Волошина, Дзюба, Жарков, Мехед, 2011).

Невербальне спілкування багатофункціональне, воно створює певний образ військового, відображає статусні відносини між комунікантами (курсант - курсант, курсант - офіцер, офіцер (нижчого звання)- офіцер (вищого звання), офіцер - цивільний), характеризує емоційнопсихічний і фізичний стан.

Для засвоєння курсантами англомовної професійно орієнтованої лексики ми пропонуємо безперекладний спосіб семантизації - розкриття значень англомовних слів, що сприятиме засвоєнню нової інформації в більшому обсязі (Азимов \& Щукин, 2009). Слідом за С. В. Смоліною (2010) до безперекладної семантизації відносимо: 1) наочну семантизацію (відеоматеріали); 2) дефініція - надання опису значення нової лексичної одиниці за допомогою відомих слів; 3) тлумачення значення нової лексичної одиниці. Автентичні професійно орієнтовані англомовні відеоматеріали дають можливість об'єднати два способи безперекладної семантизації вербальну (дефініція, тлумачення) та невербальну (наочну), таким чином ефективність запам'ятовування нових лексичних одиниць підвищується.

Висновки і перспективи подальших розвідок. Отже, ми обгрунтували основні критерії відбору відеоматеріалу для формування професійно орієнтованої компетентності в діалогічному мовленні курсантів з інформаційних систем та технологій. Узагальнили перелік типових задач і відповідних їм ситуацій, необхідних для реалізації англомовного діалогічного мовлення за професійним спрямуванням. Уточнили критерії відбору навчального лексичного та граматичного матеріалу для складання словника майбутнього військового фахівця з інформаційних систем та технологій. Перспективи подальших досліджень вбачаємо в розробці підсистеми вправ для формування професійно орієнтованої компетентності в діалогічному мовленні курсантів з інформаційних систем та технологій.

\section{ЛIТЕРАТУРА}

Азимов, Э. Г., \& Щукин, А. Н. (2009). Новый словарь методических терминов и понятий (теория и практика обучения языкам). Москва: Икар.

Борисов, В. В. (2004). Аббревиация и акронимы. Военные и научно-технические сокращчения в иностранных языках. Москва: Воениздат.

Васильченко А. А., Дормидонтов А. А., \& Нелюбин Л. Л. (1981). Учебник военного перевода. Москва: Воениздат.

Волошина, Н. М., Дзюба, М. Т., Жарков, Я. М., \& Мехед П. М. (2011). Військовий етикет i дипломатичний протокол. Київ: Україна.

Гузь, О. І. (2004). Навчання усного англомовного мовлення учнів початкової загальноосвітньої школи з використанням відеофоногнограми (Кандидатська дисертація). Київський національний лінгвістичний університет, Київ, Україна. 
Исенко, И. А. (2009). Использование испанских аутентичных фильмов для формирования социолингвистической компетентности. Научно-методчческий журнал Иностранные языки в школе. Серия: методика, 1, $79-83$.

Ковалинська, І. В. (2014). Невербальна комунікація. Київ: Освіта України.

Конопляник, Л. М., \& Коваленко, О. О. (2016). Використання автентичних відеоматеріалів для формування мовної професійно комунікативної компетентності майбутніх інженерів. Вісник Національного авіаційного університету. Серія: педагогіка, психологія, 9, 1 - 6.

Матюшин, И. М. (1996). Коммуникативная модель взаимодействия военнотерминологических систем (на материале русского и франиузского военных подъязыков) (Автореферат кандидатской диссертации). Военный университет, Москва.

Мілова, О. Є., \& Дроговоз, А. А. (2018). Скорочення як характерна риса військового тексту і шляхи їх перекладу. Науковий вісник Міжнародного гуманітарного університету. Серія. філологія, 32 (2), $172-174$.

Міністерство Оборони України. (2017). Освітньо-кваліфікаційна характеристика бакалавра (напрям підготовки: Інформачійні системи та технологіï). Київ: Україна.

Пассов, Е. И. (1989). Основы коммуникативной методики обучения иноязычному общению. Москва: Русский язык.

Пащук, В. С. (2002). Навчання студентів мовних спеціальностей усного англійського монологічного мовлення з використанням автентичних художніх фільмів (Кандидатська дисертація). Київський національний лінгвістичний університет, Київ, Україна.

Полушина, Л. П. (1995). Текстовка ученика как основа формирования социокультурной компетенции (Кандидатская диссертация). Томский государственный педагогический университет, Томск.

Сисоєва, С. О., \& Кристопчук, Т. Є. (2013). Методологія науково-педагогічних досліджень. Рівне: Волинські обереги.

Скалкин, В. Л. (1981). Основы обучения устной речи. Москвая: Русский язык.

Смоліна, С. В. (2010). Методика формування іншомовної лексичної компетенції. Іноземні мови, 4, $16-23$.

Фомина, Н. Д., \& Бакина, М. А. (1968). Фразеология современного русского языка. Москва: Университет дружбы народов.

Arthur, H. (2002). Testing for language teachers. Second edition. Cambridge: Cambridge University press.

BILC. (2019). Best Practices in STANAG 6001. Testing. Взято з https://www.natobilc.org/documents/ LanguageTesting/Best\%20Practices\%20in\%20STANAG\%206001\%20Testing\%20March\%20 2019.pdf

Common European framework of reference for languages. Council of Europe. Взято 3 https://www.coe.int/lang-CEFR

Edelhoff, C. (1985). Authentizität im Fremdsprachenunterricht. In Authentische Texte im Deutschunterricht. Einführung und Unterrichtsmodelle (S. 7-30). München, Deutschland: Christoph Edelhoff.

NATO. (1994). Glossary of communication and information systems terms and definitions. Взято $3 \mathrm{https}$ //isotranslations.com/resources/AAP-31NATO\%20GLOSSARY\%20OF\%20 COMMUNICATION \%20AND\%20INFORMATION\%20SYSTEM.pdf

NATO. (2019). Language proficiency levels. Взято 3 https://www.natobilc.org/files/ATrainP-5\%20 EDA\%20V2\%20E.pdf

NATO Standardization Office. (2019). NATO terminology manual. Взято з file://C:/Users/owner/ Downloads/ AAP-06\%202019\%20EF.pdf 


\section{REFERENCES}

Azimov, Je. G., \& Shhukin, A. N. (2009). Novyj slovar' metodicheskih terminov i ponjatij (teorija i praktika obuchenija jazykam). Moskva: Ikar.

Borisov, V. V. (2004). Abbreviacija i akronimy. Voennye i nauchno-tehnicheskie sokrashhenija $\mathrm{v}$ inostrannyh jazykah. Moskva: Voenizdat.

Vasil'chenko A. A., Dormidontov A. A., \& Neljubin L. L. (1981). Uchebnik voennogo perevoda. Moskva: Voenizdat.

Voloshyna, N. M., Dziuba, M. T., Zharkov, Ya. M., \& Mekhed P. M. (2011). Vijs'kovyj etyket i dyplomatychnyj protokol. Kyiv: Ukraina.

Huz', O. I. (2004). Navchannia usnoho anhlomovnoho movlennia uchniv pochatkovoi zahal'noosvitn'oi shkoly z vykorystanniam videofonohnohramy (Kandydats'ka dysertatsiia). Kyivs'kyj natsional'nyj linhvistychnyj universytet, Kyiv, Ukraina.

Isenko, I. A. (2009). Ispol'zovanie ispanskih autentichnyh fil'mov dlja formirovanija sociolingvisticheskoj kompetentnosti. Nauchno-metodicheskij zhurnal Inostrannye jazyki v shkole. Serija: metodika, $1,79-83$

Kovalyns'ka, I. V. (2014). Neverbal'na komunikatsiia. Kyiv: Osvita Ukrainy.

Konoplianyk, L. M., \& Kovalenko, O. O. (2016). Vykorystannia avtentychnykh videomaterialiv dlia formuvannia movnoi profesijno komunikatyvnoi kompetentnosti majbutnikh inzheneriv. Visnyk Natsional'noho aviatsijnoho universytetu. Seriia: pedahohika, psykholohiia, 9, 1-6.

Matjushin, I. M. (1996). Kommunikativnaja model' vzaimodejstvija voennoterminologicheskih sistem (na materiale russkogo i francuzskogo voennyh pod\#jazykov) (Avtoreferat kandidatskoj dissertacii). Voennyj universitet, Moskva.

Milova, O. Ye., \& Drohovoz, A. A. (2018). Skorochennia iak kharakterna rysa vijs'kovoho tekstu i shliakhy ikh perekladu. Naukovyj visnyk Mizhnarodnoho humanitarnoho universytetu. Seriia: filolohiia, 32 (2), $172-174$.

Ministerstvo Oborony Ukrainy. (2017). Osvitn'o-kvalifikatsijna kharakterystyka bakalavra (napriam pidhotovky: Informatsijni systemy ta tekhnolohii). Kyiv: Ukraina.

Passov, E. I. (1989). Osnovy kommunikativnoj metodiki obuchenija inojazychnomu obshheniju. Moskva: Russkij jazyk.

Paschuk, V. S. (2002). Navchannia studentiv movnykh spetsial'nostej usnoho anhlijs'koho monolohichnoho movlennia z vykorystanniam avtentychnykh khudozhnikh fil'miv (Kandydats'ka dysertatsiia). Kyivs'kyj natsional'nyj linhvistychnyj universytet, Kyiv, Ukraina.

Polushina, L. P. (1995). Tekstovka uchenika kak osnova formirovanija sociokul'turnoj kompetencii (Kandidatskaja dissertacija). Tomskij gosudarstvennyj pedagogicheskij universitet, Tomsk.

Sysoieva, S. O., Krystopchuk, T. Ye. (2013). Metodolohiia naukovo-pedahohichnykh doslidzhen'. Rivne: Volyns'ki oberehy.

Skalkin, V. L. (1981). Osnovy obuchenija ustnoj rechi. Moskva, Rossijskaja Federacija: Russkij jazyk.

Smolina, S. V. (2010). Metodyka formuvannia inshomovnoi leksychnoi kompetentsii. Inozemni movy $4,16-23$.

Fomina N. D., \& Bakina, M. A. (1968). Frazeologija sovremennogo russkogo jazyka. Moskva: Universitet druzhby narodov.

Arthur, H. (2002). Testing for language teachers. Second edition. Cambridge: Cambridge University press.

BILC. (2019). Best Practices in STANAG 6001. Testing. Vziato z https://www.natobilc.org/documents/ LanguageTesting/Best\%20Practices\%20in\%20STANAG\%206001\%20Testing\%20March\%20 2019.pdf

Common European framework of reference for languages. Council of Europe. Vziato z https://www.coe.int/lang-CEFR 
Edelhoff, C. (1985). Authentizität im Fremdsprachenunterricht. In Authentische Texte im Deutschunterricht. Einführung und Unterrichtsmodelle (S. 7-30). München, Deutschland: Christoph Edelhoff.

NATO. (1994). Glossary of communication and information systems terms and definitions. Vziato $\mathrm{z}$ https://isotranslations.com/resources/AAP-31-NATO\%20GLOSSARY\%20OF\%20COMMU-

NICATION\%20AND\%20INFORMATION\%20SYSTEM.pdf

NATO. (2019). Language proficiency levels. Vziato z https://www.natobilc.org/files/ATrainP-5\% 20EDA\%20V2\%20E.pdf

NATO Standardization Office. (2019). NATO terminology manual. Vziato z: file:///C:/Users/owner/ Downloads/AAP-06\%202019\%20EF.pdf 